\title{
Eduard Schaubert's Collection of Greek, Etruscan and Roman Antiques at the National Museum in Warsaw and the University Museum in Wroclaw
}

\author{
By Agata Kubala*
}

The National Museum in Warsaw and the University Museum in Wroclaw have in their possession important works of Greek, Etruscan and Roman art that are remains of the extensive collection of the $19^{\text {th }}$ century. Wroclaw architect and collector Eduard Schaubert, during his stay in Greece (1830 - 1850), had travelled throughout the country and gathered objects of ancient art. He also bought a few works during his travel to Italy. Thus, Schaubert collected this impressive set of 300 works of ancient art. After his death in 1861, his collection was donated to the Archaeological Museum in Breslau. Unfortunately, most of the antiques from Schaubert's collection perished after the World War II and they are now considered missing. Only 29 objects remained, among which are masterpieces of Greek bronze work, Attic and south Italian vases and architectural fragments with traces of the original polychrome. The very high artistic quality of preserved objects shows Schaubert's excellent knowledge of ancient Greek art. Luckily having survived the turmoil of the war, these artifacts have filled a major gap in Polish collections of ancient art which would have been poor otherwise. However, despite their great significance for our knowledge of ancient art, these objects have not yet been adequately elaborated. ${ }^{l}$

Among the ancient objects kept in the National Museum in Warsaw and the University Museum in Wroclaw there exist works of Greek, Etruscan and Roman art that have been identified as remnants of the $19^{\text {th }}$ century collection of Eduard Schaubert, a German architect and collector born in Wroclaw ${ }^{2}$. The impressive set of antiques was collected in his numerous travels in Greece during his stay in the country between 1830 and 1850. Most of the objects from Schaubert's collection are nowadays considered missing, while its creator has also been forgotten. The situation has changed only recently thanks to the International Conference held in Berlin in 2010 on the occasion of the 150th anniversary of his death ${ }^{3}$ as well as to the publications by Alexander Papageorgiou-Venetas ${ }^{4}$ and Urszula Bończuk-Dawidziuk ${ }^{5}$ devoted to him.

\footnotetext{
* Senior Lecturer, University of Wroclaw, Poland.

1. The article is meant to be a preliminary report on Schaubert's set of antiques. Dissertation discussing the entire collection forthcoming.

2. Until the end of the World War II, Wroclaw was a German city called Breslau

3. Conference program: http://bit.ly/1JnDhW9 (accessed February 15, 2015).

4. Alexander Papageorgiou-Venetas, Eduard Schaubert 1804-1860. Der Städtebauliche Nachlass zur Plannung der Städte Athen und Piräus [Eduard Schaubert 1804-1860. The Urban Estate Planning of the Cities of Athens and Piraeus] (Mannheim-Möhnesee: Harrassowitz, 2001).

5. Urszula Bończuk-Dawidziuk, "Eduard Schaubert (1804-1860)", in Schlesische Lebensbilder XI, ed. Joahim Bahlcke (Insingen: De Gruyter, 2012), 323-332.
} 
Schaubert's contributions include not only his activities as a collector but also his achievements in the field of architecture and archaeology. His interest in antiquity dates back to 1830, when he and his friend, a Greek named Stamatios Kleanthes, arrived in Greece. They were graduates of the School of Architecture in Berlin, where they had studied under the direction of Karl Friedrich Schinkel, the most important German neo-classical architect. Schaubert and Kleanthes initially worked as architects in Aegina, employed by the newly established Greek government. In 1831 they settled in Athens where they put together a complete topographical plan of Athens with its ancient ruins, medieval monuments, and the buildings of the old city. In later times, the design for the new layout of the modern capital of the newly founded Greek state was based on this plan ${ }^{6}$. In 1835, a German archaeologist Ludwig Ross invited Schaubert and a Danish architect, Hans Christian Hansen, to cooperate in the restoration of the temple of Athena-Nike on the Acropolis. The result of this cooperation was not only the reconstruction of this beautiful building; three years after the end of the works on the temple, a book on the re-erection of the temple was published written by Ross and illustrated by Schaubert and Hansen ${ }^{7}$.

Schaubert showed a strong interest in archaeology almost from the beginning of his stay in Greece. He undertook numerous travels throughout the country visiting historical places and studying ancient architecture, sculpture and inscriptions ${ }^{8}$. He also gathered objects of ancient art. The impressive set of antiques he collected consisted of more than 300 sculptures, bronzes, vases, terracottas and gems. Furthermore, Schaubert also acquired ancient coins; he could boast for his set of 1,437 Greek, Roman and Byzantine numismatic specimens. In 1850, when he came back to his hometown after 20 years spent in Greece, Schaubert brought with him to Breslau both his collections. The collection of antiques was then enriched with objects bought by Schaubert during his travel to Italy in 1854.

Schaubert died in 1860 at the age of 56. One year after his death, his legacy containing the two collections of his, manuscripts, and seven folders with documents, drawings and maps, among which the large urban plan of Athens, was handed over by his relatives to the Royal Museum of Art and Antiquities in Breslau'. At the time of this donation, Schaubert's collection of antiques contained 67 Greek and south Italian vases, 55 terracotta figurines and reliefs, 47 metal objects, 22 terracotta lamps, 23 architectural details, 13 polished marble pieces, 8 small marble sculptures, 18 arrowheads and 54 gems.

6. John Travlos, "Athens after the Liberation: Planning the New City and Exploring the Old," Hesperia. The Journal of American School of Classical Studies at Athens 50 (1981): 393.

7. Ludwig Ross, Eduard Schaubert and Christian Hansen, Die Akropolis von Athen nach den neuesten Ausgrabungen. Erste Abteilung: Der Tempel der Nike Apteros [The Acropolis of Athens after the Recent Excavations. Division One: The Temple of Nike Apteros] (Berlin: Schenk u. Gerstaecker, 1839).

8. H. R. Goette and F. Pajor, "Eduard Schaubert's Travel Notes on Southern Euboea in May 1847," Mediterranean Archaeology and Archaeometry 10, no. 3 (2010): 63.

9. In 1862 the museum changed its name to the Archaeological Museum at the University of Breslau. At present its name is the University Museum in Wrocław. 
While taking over the collection, it turned out, that Schaubert had left neither list of objects nor information about the exact spots they were found. It was August Rossbach, the director of the museum, who first ran the list of objects in his publication on the museum's collections ${ }^{10}$. The given list was, however, incomplete and some items were incorrectly identified. For instance, the small figurine of a triton was described as a dolphin with a human head ${ }^{11}$. In another guidebook to the museum, written by A. Rossbach and published in 1877, all objects from Schaubert's collection were already included, most of them with an exact description and interpretation ${ }^{12}$.

Unfortunately, most of the objects from Schaubert's collection of antiques went missing during or shortly after the World War II. No sources on the circumstances of the collection creation and the exact provenance of antiques, once being available, have also survived. Due to the preserved descriptions in A. Rossbach's publications, an attempt to restore the original composition of the collection can be undertaken, although, the loss of the vast majority of objects makes these sources unverifiable. According to the information gathered by A. Rossbach, pottery is the largest subgroup in the whole set. Among the 67 objects belonging to this group, there were mainly small blackand red-figure vases, decorated with mythological scenes, representations of warriors, women at tombs and fantastic animals or simply, with ornaments. The pottery group also contained three white-ground lekythoi, one of them $48 \mathrm{~cm}$ high, decorated with sepulchral depictions, eleven vessels without any decoration and a quantity of fragments of vessels with stamped inscriptions ${ }^{13}$. Only five vases survived which are now kept in the National Museum in Warsaw. They include two red-figure attic lekythoi, with one of them (inv. No. $198057 \mathrm{MN}$ ) dating back to $450 \mathrm{BCE}$ and being decorated with a figure of an ephebe clothed with a chlamys clasped on his right shoulder and moving to the right (see Figure 1 on the left) ${ }^{14}$. The second lekythos (inv. No $198058 \mathrm{MN}$ ) dates back to $460 \mathrm{BCE}$ and depicts a woman dressed in chiton and himation running to the right with her head towards her back. She is holding a phiale in her right hand and an unidentified object in her left hand (see Figure 1 on the right $)^{15}$.

10. See August Rossbach, Verzeichniss der Gypsabgüsse und Originalien antiker Bildwerke im Königlichen Museum für Kunst und alterthum an der Universität Breslau [List of Plaster Casts and Originals of Ancient Sculptures in the Royal Museum of Art and Antiquity at the University of Breslau] (Breslau: Grass, Barth und Comp., 1861), 38-49.

11. Ibid., 45, No. 117.

12. August Rossbach, Das archäologische Museum an der Universität zu Breslau [The Archaeological Museum at the University in Breslau] (Breslau: Buchdruckerei Lindner, 1877), 114-126.

13. August Rossbach, Das archäologische Museum an der Universität zu Breslau [The Archaeological Museum at the University in Breslau] (Breslau: Buchdruckerei Lindner, 1877), 116-120.

14. Maria Ludwika Bernhard, Corpus Vasorum Antiquorum, Pologne 6: Varsovie Musée National 3 [The Catalogue of Ancient Vases, Poland 6: Warsaw - the National Museum 3] (Warsaw: Państwowe Wydawnictwa Naukowe, 1964), pls. 38.1-2, 39.

15. Ibid., pl. 36.3-4, 37.2 
Figure 1. Attic Red-Figure Lekythoi, on the Left: Inv. No. 198057 MN, on the Right: Inv. No. 198058 MN, Height 22.5cm, Whole, Findspot Unknown, Secured in Silesia in 1946, Photographed by Piotr Ligier. Courtesy of the National Museum in Warsaw
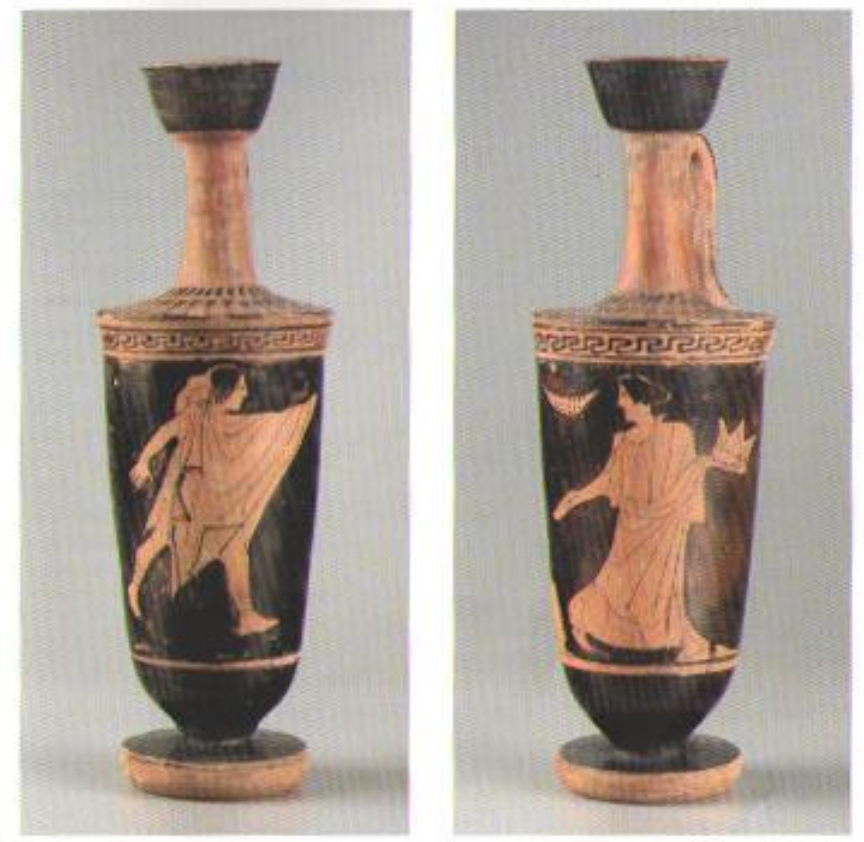

Two other preserved vases are a south Italian red-figure lekythos and an oinochoe, both dating back to the third quarter of the fourth century BCE. The Apulian aryballos-lekythos (inv. No. $198104 \mathrm{MN}$ ) is decorated with a depiction of Eros with large wings holding a tray and cymbals in his hands chasing a fleeing woman turning her head back, dressed in a chiton and holding an olive branch and a wreath in her hands. The second south Italian vase, an oinochoe (inv. No. $198927 \mathrm{MN}$ ) made in Campania, shows two persons and an altar between them (see Figure 2). The person standing on the left is a man wearing a long robe and a wreath on his head. In his right hand, he is holding a situla and in his raised left hand a box mirror can be seen, which reflects a winged figure of Eros standing on the other side of the altar. 
Figure 2. South Italian Red-Figure Oinochoe, Inv. No. 198927 MN, Height $26.5 \mathrm{~cm}$ whole, Findspot Unknown, Secured in Silesia in 1946, Photographed by Piotr Ligier. Courtesy of the National Museum in Warsaw

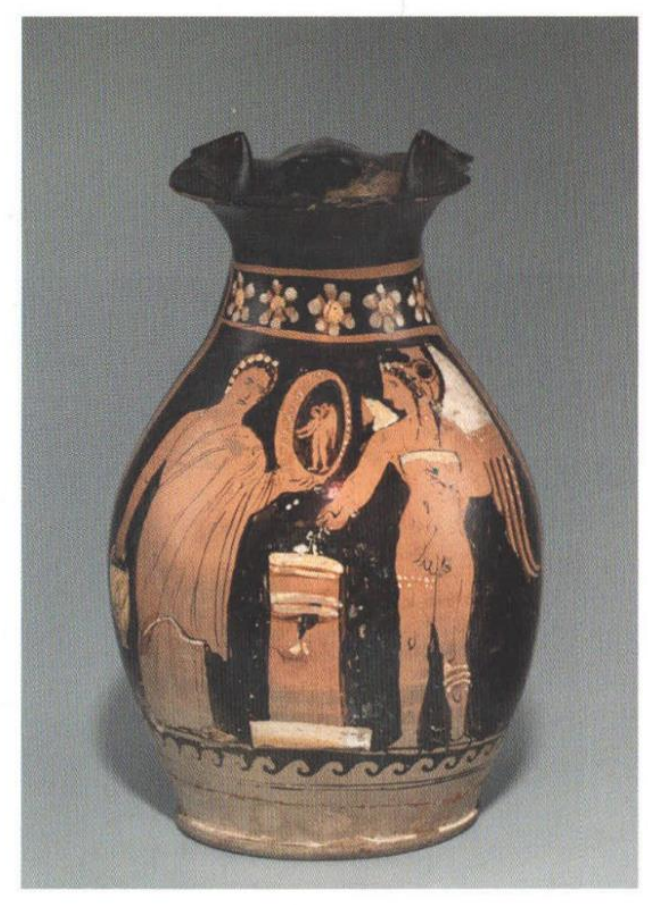

The last preserved vase is the largest of the three white-ground lekythoi once belonging to the collection ${ }^{16}$. Intended to serve as a grave gift, this Attic lekythos, attributed to the Triglyph Painter, (inv. No. 188069 MN) dates back to $430-420 \mathrm{BCE}^{17}$. Traces of the figural decoration are still visible: a seated woman holding a duck is placed on the left side of a tomb. On the opposite side, a standing man wearing a helmet is depicted (see Figure 3).

16. August Rossbach, Das Archäologische Museum an der Universität zu Breslau [The Archaeological Museum at the University in Breslau] (Breslau: Buchdruckerei Lindner, 1877), 118 , no. 1.

17. Maria Ludwika Bernhard, Corpus Vasorum Antiquorum, Pologne 5: Varsovie Musée National 2 [The Catalogue of Ancient Vases, Poland 5: Warsaw - the National Museum 2] (Warsaw: Państwowe Wydawnictwa Naukowe, 1963), pls. 50.1-3, 51.1-2, 53.2. 
Figure 3. Attic White-Ground Lekythos, Inv. No. 188069 MN, height 47.7cm, Whole, Findspot Unknown, Secured in Silesia in 1946, Photographed by Piotr Ligier. Courtesy of the National Museum in Warsaw

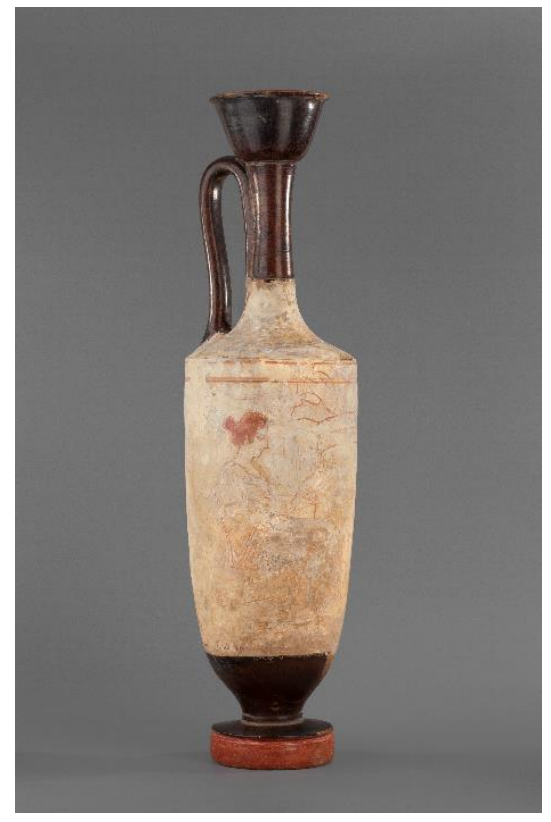

The second largest group in Schaubert's collection contains 55 terracotta figurines and reliefs. There are mainly images of Greek gods and goddesses with heads and masks among them, some of them with still visible traces of polychrome. Some objects belonging to this group, particularly Melian reliefs, were researched by Otto Rossbach, who also published this study of his, in $1889^{18}$. Only two examples of Melian terracottas are preserved until today, both belonging to the collection of the National Museum in Warsaw. They are a small fragment depicting a head of a horse and a relief, partly damaged, showing Helle riding a ram, put together by a nineteenth-century conservator, who stuck the head of the horse in place of the missing head of the ram (inv. No. 198236 MN).

Schaubert's collection also includes 47 metal objects, mainly made of bronze, 13 of which fortunately survived the turmoil of war and are now part of the main exhibition of the National Museum in Wroclaw. Among them, there exist two Greek female mirror caryatids, both of unknown provenances, which deserve special attention. They are not only excellent examples of minor Greek bronze work but also illustrate in a very clear manner the stylistic differences between archaic and early classical Greek sculpture. The older caryatid support (inv. No. $198308 \mathrm{MN}$ ) is found to date back to the third quarter of the fifth century BCE based on the visible similarities in the way of treating facial features and in a particular hairstyle, being common in the statue of Nike at Delos, dating back to the mid sixth century BCE, and in the kore no. 675 from

18. Otto Rossbach, Griechische Antiken des archäologischen Museums in Breslau, III. Bronzen [Greek Antiques of the Archaeological Museum in Breslau, III. Bronzes] (Breslau: Grass, Barth und Comp., 1889). 
the Athenian Acropolis, attributed to Archermos from Chios and dating back to about 520 BCE. ${ }^{19}$ The outfit of the caryatid may also indicate the specific island of its origin. It is most probably one of the earliest examples of mirror caryatids wearing an Ionic dress ${ }^{20}$. The caryatid under analysis is clad in a tight chiton with half-length sleeves and a short himation, put on diagonally and fastened on the right shoulder with a fibula. Our attention is drawn to her disproportionately large round head in relation to the rest of her body and her unique features; slightly slanting eyes, broad nose, high cheekbones and large mouth with lips stretched into the "archaic smile" (see Figure 4).

Figure 3. Late Archaic Mirror Caryatid, Inv. No. 198308 MN, Bronze, Total height 23.2cm, Caryatid Height 17.6cm, Foreleg of Right-Hand Horse Missing, Findspot Unknown, Secured in Silesia in 1946, Photographed by Piotr Ligier. Courtesy of the National Museum in Warsaw

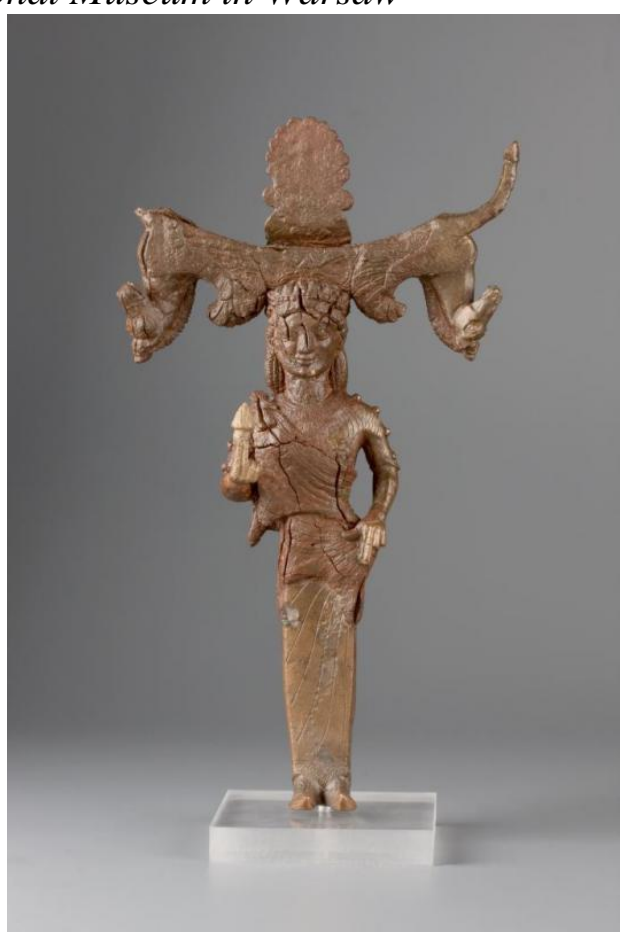

All these details have their parallels in the East Greek mirror caryatids, such as the caryatid from the George Ortiz collection ${ }^{21}$. Additionally, they also resemble to some Corinthian works such as the caryatid mirror displayed at the National Archaeological Museum in Athens with known Corinthian

19. Gisela M.A. Richter, Korai: Archaic Greek Maidens. A Study of the Development of the Kore Type in Greek Sculpture (New York: Hacker Art Books, 1988) figs. XIV-a and 396397 respectively.

20. Lenore Keene Congdon, Caryatid Mirrors of Ancient Greece (Mainz am Rhein: Philipp von Zabern, 1981), 135.

21. Karl Schefold, Meisterwerke griechischer Kunst [Masterpieces of Greek Art] (BaselStuttgart: Benno Schwabe, 1960), 222, no. 255. 
provenance $^{22}$ and the Corinthian mirror in Manchester Museum ${ }^{23}$. The unusual form of the supporting cradle also brings the Corinthian style to mind as it consists of the foreparts of two winged horses inverted upside down. It is well known that the mythical winged horse, Pegasus, was a symbol of the city of Korinthos, appearing on its coins from the very beginning of their minting ${ }^{24}$. Combining Greek onshore as well as eastern elements makes the oldest caryatid from Schaubert's collection unique in its category. It is also a very good example of the merging of different influences, which is typical for the period in which the statuette was made. It is, however, impossible to assign it to a particular school or region. L. Keene Congdon ascribes the caryatid to the eastern Greek school indicating one of the Aegean Islands as possible place of its origin ${ }^{25}$. This is very probable, for Eastern elements seem to prevail in this figurine. However, the presence of details typical for Corinthian archaic art also enables to consider it an eastern Greek imitation of a Corinthian product.

The second caryatid support (inv. No. $198310 \mathrm{MN}$ ) represents a quite tall, slender figure of a young woman slightly turned to the right, wearing a Doric dress sewn at the shoulders. On her head, there is a Y-shaped cradle with a palmette-shaped brace in the centre (see Figure 5).

22. Lenore Keene Congdon 1966, "Two Bronze Caryatid Mirrors in the National Museum of Warsaw," American Journal of Archaeology 70, no. 2 (1966): 162; Lenore Keene Congdon, Caryatid Mirrors, (Mainz am Rhein: Philipp von Zabern, 1981), 138, no. 16.

23. Thomas B.Webster, "New Antiquities in the Manchester Museum," Journal of Hellenic Studies 54 (1934): 207ff, pl. XII.

24. Peter E. Blomberg, On Corinthian Iconography. The Bridled Winged Horse and the Helmeted Female Head in the Sixth Century BC, (Acta Universitatis Uppsaliensis, 1996), 57. 1981), 135

25. Lenore Keene Congdon, Caryatid Mirrors, (Mainz am Rhein: Philipp von Zabern, 
Figure 4. Early Classical Mirror Caryatid, inv. No. 198310 MN, Bronze, Total Height 15cm, Height of Caryatid 11.4cm, Right Foot and Half of Left Foot, Right Hand and Attribute Missing, Findspot Unknown, secured in Silesia in 1946, photographed by Piotr Ligier. Courtesy of the National Museum in Warsaw

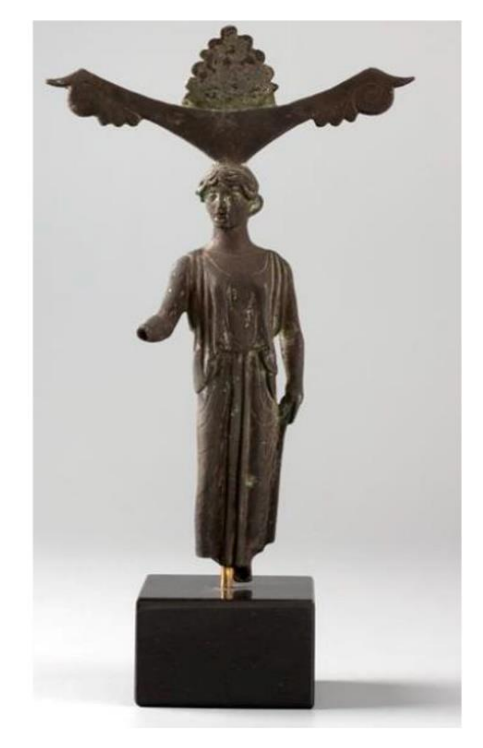

Having a strong neck, broad shoulders, and slender hips as well as these specific details of the garment and coiffure, the figurine strongly resembles caryatids of stand mirrors produced in the Sikyonian workshop of great renown, known to have existed in ancient Sikyon $^{26}$. Best analogies for the object under discussion are found in the caryatid of the mirror said to originate from Corinth, now belonging to the Glyptothek und Museum kleiner Kunst in Munich (inv. No. 3634) ${ }^{27}$, the caryatid found in Attica, at present being in the collection of the National Archaeological Museum in Athens (inv. No. 7399) ${ }^{28}$, and the caryatid of the mirror found in a grave at Tragana near the ancient Sikyon $^{29}$. All the cited examples, dating back to 465-455 BCE, are undoubtedly attributed to the Sikyonian School. It is therefore reasonable to assign the second caryatid from Schaubert's collection to the same series. It can also be concluded that it dates back to the same period.

In the caryatid mirrors collection, there also were three very small figurines representing two hounds and a rooster. A. Rossbach described them

26. Ibid., 61

27. Ibid., No. 53, pls. 48, 49.

28. Ibid., No. 72, pl. 66.

29. David M. Robinson and Elizabeth Pierce Blegen, "Archaeological News and Discussions," American Journal of Archaeology 41, no. 2 (1937): 337, fig. 3. The present location of the mirror is unknown. 
as toys, which was an incorrect identification of their functions ${ }^{30}$. It is very likely, that he did not have a comparative material in the form of complete Greek stand mirrors, whose reflecting discs were in many cases decorated with images of animals, birds and mythical creatures such as sirens. The finely made figure of the rooster (inv. No. $198356 \mathrm{MN}$ ) depicted in the front has its feet joined together making a kind of a narrow base in order to fix it to a mirror's disc. With respect to the proportions and the way of elaborating of the body as well as the particular details such as the feathers of the wings and the tail, it can be concluded that the figure under analysis clearly resembles roosters decorating discs of caryatid mirrors belonging to the main exhibition of the Badisches Landesmuseum at Karlsruhe (inv. No. 1867) ${ }^{31}$ and to the Louvre (inv. No. Br.1687). ${ }^{32}$ All these exhibits are products of a Corinthian workshop and date back to 470-460 BC. Despite the fact that the spot where the Warsaw cock's figurine was found remains unknown, the parallels with roosters decorating Corinthian mirrors allow us to attribute it to the same school.

Two figurines of running animals (inv. Nos. $198354 \mathrm{MN}$ and $198355 \mathrm{MN}$ ) were described by A. Rossbach and L.O. Keene Congdon as foxes ${ }^{33}$. Indeed, with their short, pointed ears, rather short and stocky bodies and long tails they strongly resemble these predators. Good analogies for them are running foxes decorating the disc of the caryatid mirror said to be from Megara, now belonging to the collection of the Staatliche Museen $\mathrm{zu}$ Berlin, Antikensammlung (inv. No. MI 7103). The exhibit in Berlin dates back to 465$460 \mathrm{BC}$ and it is quite representative of the "Argive-Corinthian" school ${ }^{34}$, with hounds chasing hares being visible on the disc of the cited above caryatid mirror found at Tragana (see footnote 29), most probably produced in a Sikyonian atelier. Both running animals from Schaubert's collection could be therefore defined as products of a Peloponnesian workshop located in Corinth, Argos or Sikyon. The width of their paws is the same as that of the rooster (in all three cases it is $0,5 \mathrm{~cm}$ ) which may indicate, that they once decorated the same mirror. As it was shown above, the rooster can be attributed to the "Corinthian" school. Therefore, ancient Corinth may be pointed out as the place of the production of both running animals as well. Their interpretation as foxes should be reconsidered, for they may also be images of the Vulpine hound, a hybrid between a dog and a fox, which according to Xenophon, was

30. August Rossbach, Das archäologische Museum an der Universität zu Breslau [The Archaeological Museum at the University in Breslau] (Breslau: Buchdruckerei Lindner, 1877), 125 , no. 29.

31. Karl Schumacher, Beschreibung der Sammlung Antiken Bronzen [Description of the Collection of Ancient Bronzes] (Karlsruhe: Bielefeld, 1890), 34, no. 223, pl. IV,2.

32. André de Ridder, Les bronzez antiques du Musée du Louvre: Tome premier: Les figurines [Ancient Bronzes from the Louvre Museum: Volume One: Figurines] (Paris: Braun, 1913), 43, pl. 77, no. 1687.

33. August Rossbach, Das Archäologische Museum an der Universität zu Breslau [The Archaeological Museum at the University in Breslau] (Breslau: Buchdruckerei Lindner, 1877), 125, no. 29; Lenore Keene Congdon, Caryatid Mirrors, (Mainz am Rhein: Philipp von Zabern, 1981), nos. 15 and 16.

34. Lenore Keene Congdon, Caryatid Mirrors (Mainz am Rhein: Philipp von Zabern, 1981), 163, no. 48 , pl. 43 . 
one of the two kinds of hounds widely used in ancient Greece and resembled a fox. The most common game was hunting hares, which are usually chased animals shown on completely preserved caryatid mirrors.

The last preserved object from Schaubert's collection, recognized as part of a caryatid mirror, is a round base, $3,5 \mathrm{~cm}$ high and $4,9 \mathrm{~cm}$ wide, set on three supports in the form of paws of a feline ending at the top with volutes (inv. No. $198315 \mathrm{MN}$ ). On the upper surface of the base, there are still visible traces of a caryatid which appears to had been once fixed in that place. The type of base represented by the Warsaw object seems to be typical for Peloponnesian caryatid mirrors. Comparisons with bases of mirrors of the same type show that the greatest similarity can be found between the object under analysis and the bases of the caryatid mirrors in the Atkins Museum of fine Arts in Kansas City (inv. No. 60-84) 3 $^{35}$ and in the Badisches Landesmuseum in Karlsruhe ${ }^{36}$. They have the same form of a tripod with feline legs joined to the lower platform by a rectangular plate with rounded lower corners. Their common elements are also the beadings under their upper rims. L. Keene Congdon argues that both cited mirrors belong to the "Corinthian" school and date back to 465-460 BC. Therefore, it may be assumed, that the base in question was once a part of a stand mirror made at approximately the same time in Corinth or in a workshop closely related to the "Corinthian" school.

The collection under analysis also contained another type of a Greek mirror, the so-called hand mirror, a fine example of which was found by Kazimierz Michałowski to date back to the end of the sixth century BC (inv. No. $198287 \mathrm{MN})^{37}$. The reflecting disc of this artifact presented here, being slightly convex on one side, was cast with a handle whose edges are folded up. The back side of the disc bears no traces of decoration. The find-spot of the mirror remains unknown; however, the shape of its handle is very similar to those of Corinthian hand mirrors ${ }^{38}$. It therefore seems reasonable to consider the hand mirror from Schaubert's collection as a product of a Corinthian workshop.

It is argued that the cover of a box mirror (inv. No. $198294 \mathrm{MN}$; diameter $14 \mathrm{~cm}$ ) holds the characteristics of the $\mathrm{C}$ category of form, according to $\mathrm{W}$. Züchner's division of preserved mirrors of this type ${ }^{39}$. The ornament of a plait surrounded with concentric circles, embossed around the edge of the cover, (see Figure 6) allows us to assign to the cover the variant $\mathrm{C} 1$ for which it is

35. Lenore Keene Congdon, Caryatid Mirrors (Mainz am Rhein: Philipp von Zabern, 1981), 169, no. 58, pl. 53.

36. See footnote 31 .

37. Kazimierz Michałowski, Sztuka starożytna [Ancient Art] (Warsaw: Wydawnictwo Sztuka, 1955), 230; see also August Rossbach, Das archäologische Museum an der Universität zu Breslau [The Archaeological Museum at the University in Breslau], (Breslau: Buchdruckerei Lindner, 1877), 124, no. 15.

38. See for instance Humfrey Payne, Necrocorinthia. A study of Corinthian Art in the Archaic Period (Oxford: Clarendon Press, 1931), 228, fig. 103B.

39. Wolfgang Züchner, Griechische Klappspiegel [Greek Box Mirrors] (Berlin: de Gruyter, 1942), 42. 
typical $^{40}$. The cover is decorated with a relief scene, showing a couple interpreted as depictions of Zeus and Hera seated cross-legged on a rock. The man is almost naked, with only a coat thrown over his left shoulder, while the woman is dressed with a long chiton with no sleeves and a himation rolled on her tights and covering her legs. Zeus is touching with his left hand the right wrist of Hera seated opposite to him. The theme of decoration and the manner of its executions resemble objects made at the end of the fourth or the beginning of the third century B.C. ${ }^{41} 300$ B.C. or the period shortly after may therefore be defined as the time of creation of the discussed objects.

Figure 5. Cover of a Box Mirror, Inv. No. 198294 MN, Bronze, Diam. $14 \mathrm{~cm}$, Relief Decoration Partly Damaged, 300 B.C. or Shortly after, Findspot Unknown, Secured in Silesia in 1946, Photographed by Piotr Ligier. Courtesy of the National Museum in Warsaw

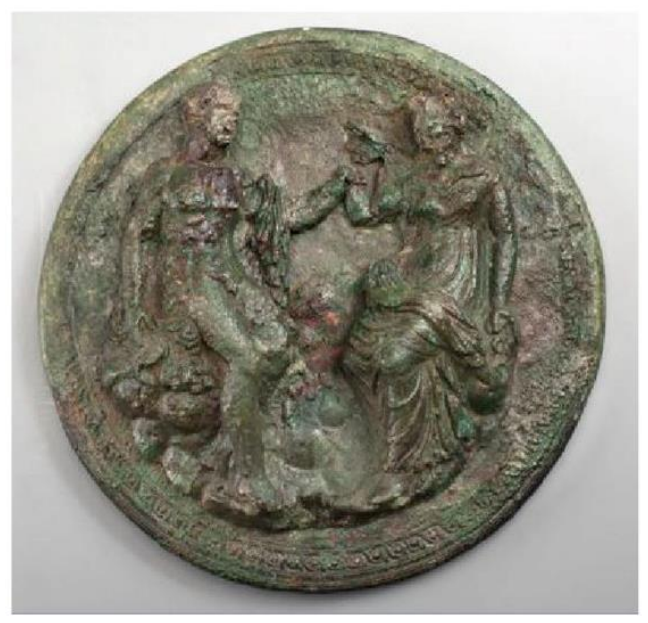

The Corinthian helmet (inv. No. 198283 MN) from Schaubert's set of antiques is the oldest one of three Greek helmets of this type belonging to polish collections. According to the information given to A. Rossbach by Otto Schaubert, Eduard Schaubert's nephew, the helmet has been found at Mycenae $^{42}$. It is made of a single bronze sheet and decorated with a geometric ornament along the edges. In the rear lower part of the helmet, protecting the neck, there are two small holes placed within a distance of $0.5 \mathrm{~cm}$. Three similar holes were probably in its upper part, in the place which is now missing. It is quite possible, that they once served to attach a crest to the helmet.

40. Agnes Schwarzmeier, Griechische Klappspiegel. Untersuchungen zu Typologie und Stil [Greek Box Mirrors. Studies on Typology and Style] (Berlin: Mitteilungen des Deutschen Archäologischen Institut, Athenische Abteilung 18, 1997), 12.

41. Ibid., 240 , cat. no. 32 , pl. $16 ; 247$, cat. no. 30 , pl. $17 ; 319$ f, cat. no. 209 , pl. $17 ; 307$, cat. no. 181, pl. 16.

42. August Rossbach, Das archäologische Museum an der Universität zu Breslau [The Archaeological Museum at the University in Breslau] (Breslau: Buchdruckerei Lindner, 1877), 123, no. 1. 
The shape of the helmet from Schaubert's collection is almost identical to this of the helmet no. M 351, being found at Olympia and dating back to the fourth quarter of VII century BCE. ${ }^{43}$ A. Snodgrass, who divides Corinthian helmets made up until $600 \mathrm{BCE}$ into three groups assigns the discussed helmet to the last group referred to as "the first" classical" phase of the Corinthian helmet" and belonging to the late seventh century $\mathrm{BCE}^{44}$. This group is conterminous with the so-called "Myros group", defined by E. Kunze and argued to belong to the $650-570 \mathrm{BCE}$ period ${ }^{45}$. In the light of many common characteristics to helmets attributed to the younger phase of the "Myros group", dating the Warsaw helmet to the period between 630 and $600 \mathrm{BCE}$ as proposed by $\mathrm{K}$. Ciałowicz ${ }^{46}$ seems quite reasonable.

Another object worth noticing is the south Italian round; this flat plate with the raised wide edge dating back to the archaic period and being found at Delphi, according the information provided by O. Schaubert (inv. No. 198282 $\mathrm{MN})^{47}$. The large plate, whose diameter is $46 \mathrm{~cm}$, has two horizontal handles, the upper surfaces of which are ornamented with patterns of a plaiting. Additionally, on both sides of each handle big buds are growing.

The Etruscan figurine of the triton, dating back to the first quarter of the fifth century BC (inv. No. $198311 \mathrm{MN})^{48}$ and the handle of a vessel decorated in its lower part with an image of a silenus (inv. No. 198309 MN), recognized as an Etruscan work and dating back to the beginning of the fifth century $\mathrm{BCE}^{49}$, are also noteworthy.

Of Roman origin is the support in the shape of a foot of a large bird, probably an eagle, dating back to the time of Trajan (inv. No. $198364 \mathrm{MN}$ )

43. Heide Frielinghaus, Die Helme von Olympia. Ein Beitrag zu Waffeweihungen in Griechischen Heiligtümern [Helmets from Olympia. A Contribution to Weapons Dedications in Greek Sanctuaries] Olympische Forschungen XXXIII (Berlin: de Gruyter, 2011), 347f, pl. 36,3-4.

44. Anthony Snodgrass, Early Greek Armour and Weapons. From the End of the Bronze Age to 600 B.C. (Edinburgh: Edinburgh University Press, 1964), 23.

45. Emil Kunze, VIII Bericht über die Ausgrabungen in Olympia [VIII Report on the Excavations in Olympia] (Berlin: de Gruyter, 1961), 77.

46. Krzysztof M. Ciałowicz, "Casques Corinthiens dans les Collections Polonaises" ["Corinthian Helmets in Polish Collections"] Études et Travaux. Travaux du Centre d' Archéologie Méditerranéenne de l'Academie Polonaise des Sciences XIII (1981): 49f.

47. August Rossbach, Das Archäologische Museum an der Universität zu Breslau [The Archaeological Museum at the University in Breslau] (Breslau: Buchdruckerei Lindner, 1877), 123, no. 2.

48. August Rossbach, Das Archäologische Museum an der Universität zu Breslau [The Archaeological Museum at the University in Breslau] (Breslau: Buchdruckerei Lindner, 1877), 124, no. 26; Witold Dobrowolski, "Les Modifications de la Manière de Presenter Triton dans l'art Étrusque de L'archaisme Tardif" ["Changes in the Manner of Presenting Triton in Etruscan Art of the late Archaism"] in Mélanges offerts à Kazimierz Michałowski, ed. Maria Ludwika Bernhard (Warsaw: Państwowe Wydawnictwa Naukowe, 1966), 375ff, figs. 2, 4.

49. August Rossbach, Das archäologische Museum an der Universität zu Breslau [The Archaeological Museum at the University in Breslau] (Breslau: Buchdruckerei Lindner, 1877), 125, no. 34; Otto Rossbach, Griechische Antiken des Archäologischen Museums in Breslau, III. Bronzen [Greek Antiques of the Archaeological Museum in Breslau, III. Bronzes] (Breslau: Grass, Barth und. Comp., 1889), 42, no. 43. 
The last preserved bronze object which can be dated back to the early Byzantine period is the figurine of a winged woman, flattened at the back. She is dressed with a robe with long sleeves and a diagonally put sash adorned with signs of a cross. The woman is holding a bowl or a basket on her head (inv. No. $198347 \mathrm{MN})^{50}$.

Particularly interesting was the group of 23 terracotta, marble, and limestone architectural details, most of them with partly preserved original polychrome $^{51} .15$ of them survived the post-war pillage and are now kept in the University Museum in Wroclaw. Among the preserved objects, there are six clay antefixes, one gargoyle in the form of a lion's head with the fragment of the adjacent sima, and eight stone, painted dark red and blue architectural fragments of different sizes ${ }^{52}$. They belong to the latest found components of Schaubert's collection only being identified as belonging to this set in 2011 .

Of the six antefixes which can now be seen in the University Museum, three are complete with a height of $27 \mathrm{~cm}$,(inv. Nos. UW-12; UW-14; UWr-78VIIj-5-4), while the upper part of the palmette of one of them is damaged (inv. No. UWr-78-VIIj-5-2) and only the lower parts of the two remaining ones are preserved (inv. Nos. UWr-78-VIIj-5-1; UWr-78-VIIj-5-5). The provenance of all antefixes being unfortunately unknown, it is, however, very possible, that most of them come from Athens or its surrounding regions, where E. Schaubert lived for many years. Only one artefact seems to be of south Italian origin (inv. No. UWr-78-VIIj-5-5). Based on stylistic comparisons, an attempt could be made to date the Wroclaw antefixes. None of them seems to be older than the last quarter of the fifth century BCE. One of them two partly preserved specimens may be dated back to the period after the fifth century (inv. No. UWr-78-VIIj-5-1, see Figure 7) because of its clear similarity to antefixes of the Erechtheion ${ }^{53}$, especially in the decoration of the lower part. It can be regarded as an imitation of the temple's roof decorative elements.

50. August Rossbach, Das Archäologische Museum an der Universität zu Breslau [The Archaeological Museum at the University in Breslau] (Breslau: Buchdruckerei Lindner, 1877), 125 , no. 37.

51. Ibid., 115f, nos. 1-23.

52. Ibid.,, $115 f$.

53. John Travlos, Pictorial Dictionary of Ancient Athens (London: Thames and Hudson Ltd., 1971), 223, fig. 287. 
Figure 6. Lower Part of Terracotta Antefix, Inv. No. UWr-78-VIIj-5-1, Height $15 \mathrm{~cm}$, Upper Part Missing, Findspot Unknown, Donated by E. Schaubert's Inheritors in 1861, Photographed by Wojciech Matkowicz. Courtesy of the University Museum in Wroctaw

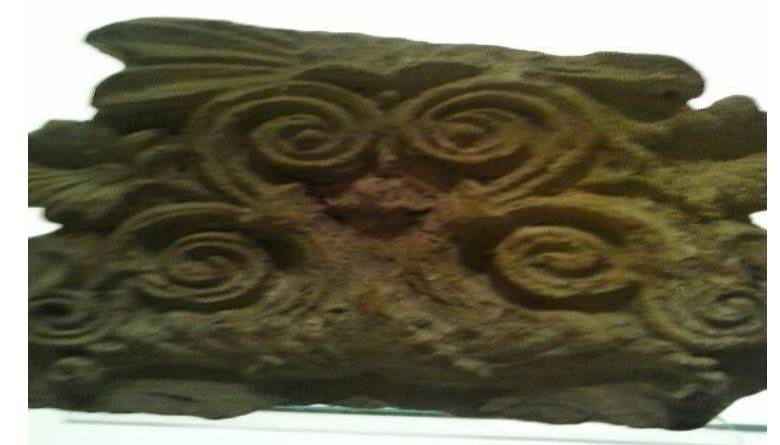

Another antefix (inv. No. UWr-78-VIIj-5-2, see Figure 8), as well as the gargoyle (inv. No. UWr-78-VIIj-7-1), most probably date back to the second part of the fourth century $\mathrm{BCE}$, as the comparisons with the corresponding objects from Corinth also dating back to the same period ${ }^{54}$ indicate. $^{-}$

Figure 7. Terracotta Antefix, Inv. No. UWr-78-VIIj-5-2, height $25 \mathrm{~cm}$, Upper Part Of Palmette Damaged, Findspot Unknown, Donated by E. Schaubert's Inheritors in 1861, Photographed by Wojciech Matkowicz. Courtesy the University Museum in Wroctaw

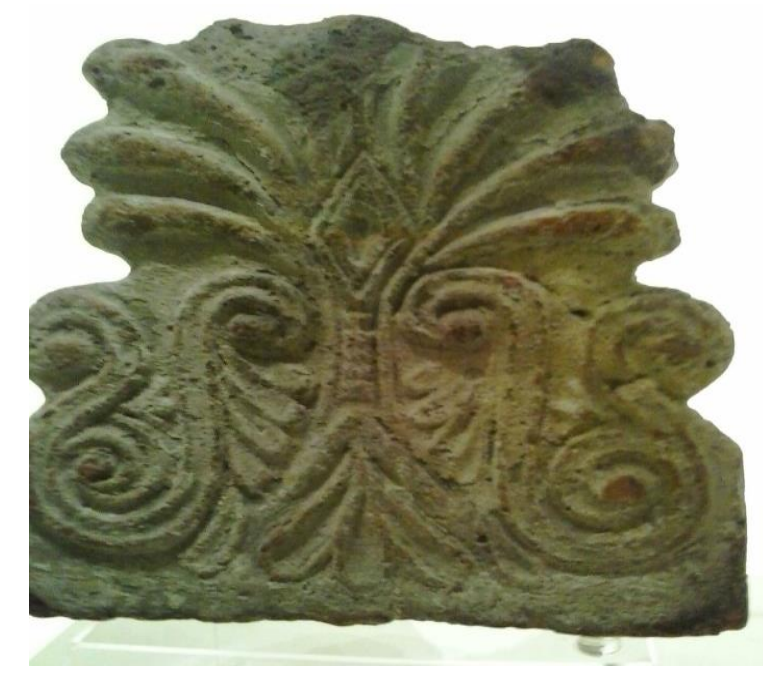

The antefix is also very similar to one of those coming from a very problematic structure known as "Dörpfeld's Enneakrounos", uncovered during the German excavations carried out between 1892 and 1897 in the region

54.See for instance Marie-Christine Hellman, L'architecture Grecque, 1: Les principes de la construction [Greek Architecture, 1: The Principles of the Construction] (Paris: Picard, 2001), 304, fig. 416. 
southwest of Areopagus at Athens ${ }^{55}$. Two other antefixes (, inv. Nos. Uw-14 and UWr-78-VIIj-5-4, see Figures 9 and 10) from the former Schaubert's collection also find the best analogies in the small decorative terminations once put at the eaves of the roof of the same structure ${ }^{56}$.

Figure 8. Terracotta Antefix, Inv. No. UW-14, Whole, Height $25 \mathrm{~cm}$, Findspot Unknown, Donated by E. Schaubert's Inheritors in 1861, Photographed by Wojciech Małkowicz. Courtesy of the University Museum in Wrocław

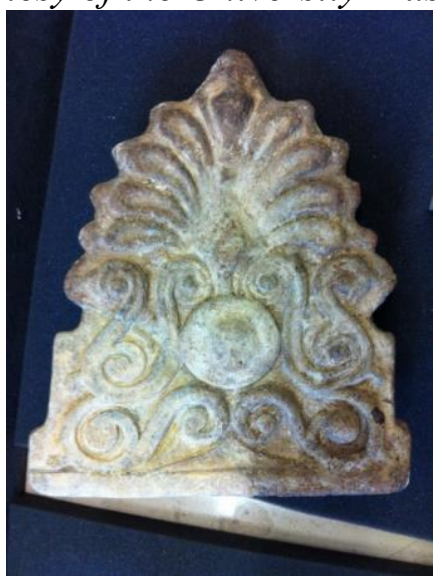

Figure 9. Terracotta Antefix, Inv. No. UWr-78-VIIj-5-4, whole, height 27, Findspot Unknown, Donated by E. Schaubert's inheritors in 1861, Photographed by Wojciech Matkowicz. Courtesy of the University Museum in Wroctaw

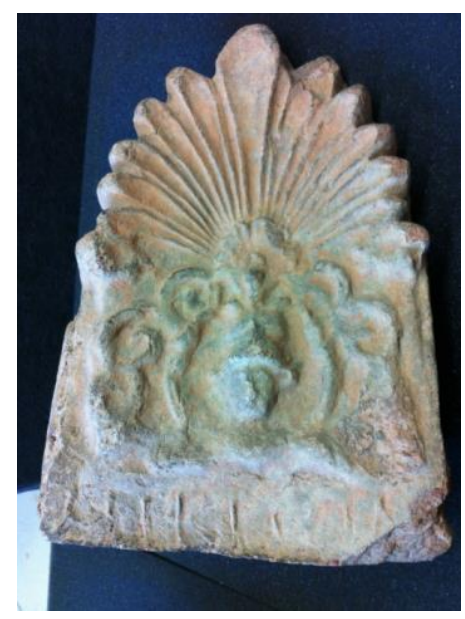

22 terracotta lamps, eight small marble sculptures with an average height of $14 \mathrm{~cm}$, bronze and stone arrowheads, according to the information given by

55. Homer A. Thompson and Richard Ernest Wycherley, The Athenian Agora, vol. XIV: The Agora of Athens. The History, Shape and Uses of an Ancient City Center (Princeton: American School of Classical Studies at Athens, 1972), 199; see also http://bit.ly/1MdNz8B (accessed March 01, 2015).

56. Antefix with Palmette: 143834, http://bit.ly/1FWhGo9; Antefix with Palmette: 143835 http://bit.ly/1MYrAWi. 
O. Schaubert, were found on the battlefield at Marathon ${ }^{57}$. Finally, 69 gems appear to have complemented the collection. Unfortunately, none of these objects has survived until today.

In view of the fact that the overwhelming majority of the objects from the collection of the Wroclaw architect are now considered missing, a scientific assessment of the entire set remains only a hypothesis. However, the high artistic quality of the preserved specimens testifies to the refined eye of the collector who perfectly knew ancient Greek art and was strongly embedded in the history of the Hellenic archaeology during the first years of Greece's independence.

\section{Bibliography}

Antefix: 143809, http://arachne.uni-koeln.de/item/objekt/143809 (accessed March 01, 2015).

Antefix with Palmette: 143834, http://arachne.uni-koeln.de/item/objekt/143834 (accessed March 01, 2015).

Antefix with Palmette: 143835, http://arachne.uni-koeln.de/item/objekt/143835 (accessed March 01, 2015).

Bernhard, Maria Ludwika. Corpus Vasorum Antiquorum, Pologne 5: Varsovie Musée National 2. Warsaw: Państwowe Wydawnictwa Naukowe, 1963.

Bernhard, Maria Ludwika. Corpus Vasorum Antiquorum, Pologne 6: Varsovie Musée National 3. [The Catalogue of Ancient Vases, Poland 6: Warsaw - the National Museum 3]. Warsaw: Państwowe Wydawnictwa Naukowe, 1964.

Bloomberg, Peter E. On Corinthian Iconography. The Bridled Winged Horse and the Helmeted Female Head in the Sixth Century BC. Acta Universitatis Upsaliensis, 1996.

Bończuk-Dawidziuk, Urszula. "Eduard Schaubert (1804 - 1860)". In Schlesische Lebensbilder XI, edited by Joachim Bahlcke, 323-332. Insingen: De Gruyter, 2012.

Ciałowicz, Krzysztof M. "Casques Corinthiens dans les Collections Polonaises" ["Corinthian Helmets in Polish Collections"]. Études et Travaux. Travaux du centre d'archéologie méditerranéenne de l'Academie Polonaise des Sciences XIII (1981): 48-52.

De Ridder, André. Les bronzes antiques du Musée du Louvre: Tome Premier: Les figurines [Ancient Bronzes from the Louvre Museum: Volume One: Figurines]. Paris: Braun, 1913.

Dobrowolski, Witold. "Les modifications de la manière de presenter Triton dans l'art étrusque de l'archaisme tardif." ["Changes in the Manner of Presenting Triton in Etruscan Art of the late Archaism"] In Mélanges offerts à Kazimierz Michałowski, edited by Maria Ludwika Bernhard, 375-380. Warsaw: Panśtwowe Wydawnictwa Naukowe, 1966.

Frielinghaus, Heide. Die Helme von Olympia. Ein Beitrag zu Waffeweihungen in griechischen Heiligtürmen [Helmets from Olympia. A Contribution to Weapons

57. August Rossbach, Das archäologische Museum an der Universität zu Breslau [The Archaeological Museum at the University in Breslau], (Breslau: Buchdruckerei Lindner, 1877), 123, no. 11 
Dedications in Greek Sanctuaries]. Olympische Forschungen, XXXIII. Berlin: de Gruyter 2011.

Goette, H. R., and Pajor, F. "Eduard Schaubert's Travel Notes on Southern Euboea in May 1847." Mediterranean Archaeology and Archaeometry 10, no. 3 (2010): 6364.

Hellman, Marie- Christine. L'architecture grecque, 1: Les principes de la construction [Greek Architecture, 1: The Principles of the Construction]. Paris: Picard, 2001.

Keene Congdon, Lenore. "Two Bronze Caryatid Mirrors in the National Museum of Warsaw. " American Journal of Archaeology 70, no. 2 (1966): 161-165.

Keene Congdon, Lenore. Caryatid Mirrors of Ancient Greece. Mainz am Rhein: Philipp von Zabern, 1981.

Kunze, Emil. VIII Bericht über die Ausgrabungen in Olympia [VIII Report on the Excavations in Olympia]. Berlin: de Gruyter, 1961.

Michałowski, Kazimierz. Sztuka starożytna [Ancient Art]. Warsaw: Wydawnictwo Sztuka, 1955.

Papageorgiou-Venetas, Alexander. Eduard Schaubert 1804-1860. Der Städtebauliche Nachlass zur Plannung der Städte Athen und Piräus [Eduard Schaubert 18041860. The Urban Estate Planning of the Cities of Athens and Piraeus]. Mannheim-Möhnesee: Harrassowitz, 2001.

Payne, Humfry. Necrocorinthia. A Study of Corinthian Art in the Archaic Period. Oxford: Clarendon Press, 1931.

Richter, Gisela M.A. Korai: Archaic Greek Maidens. A Study of the Development of the Kore Type in Greek Sculpture. New York: Hacker Art Books, 1988.

Robinson David M, and Pierce Blegen Elizabeth. "Archaeological News and Discussions." American Journal of Archaeology 41, no. 2 (1937): 315-338.

Ross, Ludwig, Schaubert, Eduard, and Hansen, Christian. Die Akropolis von Athen nach den neuesten Ausgrabungen. Erste Abteilung: Der Tempel der Nike Apteros [The Acropolis of Athens after the Recent Excavations. Division One: The Temple of Nike Apteros]. Berlin: Schenk u. Gerstaecker, 1839.

Rossbach, August. Verzeichniss der Gypsabgüsse und Originalien antiker Bildwerke im Königlichen Museum für Kunst und Alterthum an der Universität Breslau [List of Plaster Casts and Originals of Ancient Sculptures in the Royal Museum of Art and Antiquity at the University of Breslau]. Breslau: Grass, Barth und Comp., 1861.

Rossbach, August. Das archäologische Museum an der Universität zu Breslau [The Archaeological Museum at the University in Breslau]. Breslau: Buchdruckerei Lindner, 1877.

Rossbach, Otto. Griechische Antiken des archäologischen Museums in Breslau, III. Bronzen [Greek Antiques of the Archaeological Museum in Breslau, III. Bronzes]. Breslau: Grass, Barth und. Comp., 1889.

Schumacher, Karl. Beschreibung der Sammlung antiken Bronzen [Description of the Collection of Ancient Bronzes]. Karlsruhe: Bielefeld, 1890.

Schefold, Karl. Meisterwerke griechischer Kunst [Masterpieces of Greek Art]. BaselStuttgart: Benno Schwabe, 1961.

Schwarzmeier, Agnes. Griechische Klappspiegel. Untersuchungen zu Typologie und Stil [Greek Box Mirrors. Studies on Typology and Style]. Berlin: Mitteilungen des Deutschen Archäologischen Instituts, Athenische Abteilung 18, 1997.

Snodgrass, Anthony. Early Greek Armour and Weapons. From the End of the Bronze Age to 600 B.C. Edinburgh: Edinburgh University Press, 1964. 
Thompson Homer A., and Wycherley Richard Ernest. The Athenian Agora, vol. XIV: The Agora of Athens. The History, Shape and Uses of an Ancient City Center. Princeton: American School of Classical Studies at Athens, 1972.

Travlos, John. Pictorial Dictionary of Ancient Athens. London: Thames and Hudson Ltd., 1971.

Travlos, John. "Athens after the Liberation: Planning the New City and Exploring the Old." Hesperia. The Journal of American School of Classical Studies at Athens 50 (1981): 391-407.

Webster, Thomas B. "New Antiquities in the Manchester Museum." Journal of Hellenic Studies 54 (1934): 207-209.

Züchner, Wolfgang, Griechische Klappspiegel [Greek Box Mirrors]. Berlin: de Gruyter, 1942. 
